Acta Universitatis Nicolai Copernici • Pedagogika XLI/1/2021

Nauki Humanistyczno-Społeczne • Zeszyt 453

DOI: http://dx.doi.org/10.12775/AUNC_PED.2021.007

\author{
Alicja Korzeniecka-Bondar \\ University of Bialystok \\ ORCID: 0000-0003-1145-2996
}

\title{
Absorbed by Everyday Life - Students' Experience of the Changing Grammar of Schooling During the Coronavirus Pandemic
}

\begin{abstract}
This paper reports the findings of the study of selected elements of grammar of schooling (temporal and spatial organization, learning interactions). The study presented in this article focuses on the experiences of 641 st year pedagogy students' who had learned in the coronavirus pandemic. The data were collected through questionnaire with open-ended questions about the changes students experienced due to the coronavirus pandemic in areas such as the organisation of space, the organisation of time, learning interactions, forms of work, as well as the expected consequences of the changes they are currently witnessing and the anticipated 'return to normality'. The article presents the findings related to changes in three elements of the grammar of schooling: (1) spatial organization; (2) temporal organization; and (3) educational interactions. The results of the study indicate that students had to reorganize their space-time due to receiving the educational process from home. Students feel swallowed up by everyday life - the educational process has become one of many routine daily activities. They experience a change in privacy boundaries, which has consequences for other family members as
\end{abstract}


well. Students' relationships with teacher educators are still formal and centered around the content being taught. Relationships with peers have weakened considerably.

Ke y w ord s: pandemic, grammar of schooling, everyday experiences, studying

\section{Streszczenie}

Badania przedstawione $\mathrm{w}$ artykule koncentrują się na doświadczeniach 64 studentów I roku pedagogiki, którzy realizują proces kształcenia w warunkach pandemii koronawirusa. Dane zostały zebrane za pomocą kwestionariusza z pytaniami otwartymi na temat zmian, jakich doświadczyli studenci w związku z pandemią koronawirusową w takich obszarach, jak organizacja przestrzeni, organizacja czasu, interakcje uczenia się, formy pracy, a także spodziewane konsekwencje zmian, których są obecnie świadkami, oraz przewidywany „powrót do normalności”. W artykule przedstawiono ustalenia dotyczące zmian $\mathrm{w}$ trzech elementach gramatyki szkolnej: (1) organizacji przestrzennej; (2) organizacji czasowej; oraz (3) interakcji edukacyjnych. Wyniki badań wskazują, że studenci musieli przeorganizować swoją czasoprzestrzeń w związku z realizowaniem procesu kształcenia z domu. Studenci czują się pochłonięci przez codzienność - proces edukacyjny stał się jedną z wielu rutynowych, codziennych czynności. Doświadczają zmiany granic prywatności, co ma konsekwencje również dla innych członków rodziny. Relacje studentów z nauczycielami akademickimi są nadal formalne i skoncentrowane wokół nauczanych treści. Relacje z rówieśnikami uległy znacznemu osłabieniu.

Słowa kluczowe: pandemia, gramatyka edukacji, codzienne doświadczenia, studiowanie 


\section{Introduction}

The coronavirus pandemic has changed nearly all the aspects of 1 human life: health ${ }^{1}$, daily activities ${ }^{2}$, work, consumption ${ }^{3}$, education $^{4}$, communication $^{5}$, the market and finance ${ }^{6}$, etc. We are experiencing a traumatic crisis, an unexpected situation generating the sense of danger and intense emotions". The COVID "checking up" (of how we

1 WHO, COVID-19 Strategy Update. World Health Organization, 2020, https://www.who.int/docs/default-source/coronaviruse/COVID-strategy-update14april2020.pdf?sfvrsn=29da3ba0_19 [access date: 2021-02-08].

${ }^{2}$ H. Ali, G. Yilmaz, Z. Fareed, F. Shahzad, M. Ahmad. Impact of novel coronavirus (COVID-19) on daily routines and air environment: evidence from Turkey. "Air Quality, Atmosphere \& Health", 2021 no 14, p. 381-387, https://doi.org/10.1007/ s11869-020-00943-2.

${ }^{3}$ G. L. Gardini, ed., The World before and after COVID - 19. Intellectual reflections on politics, diplomacy and international relations, Salamanca - Stockholm, European Institute of International Studies, 2020.

M. Kituyi, I. Durant, D. Owoko, et al., The Impact of the COVID-19 Pandemic on Trade and Development: Transitioning to a New Normal, New York, 2020.

F. Gaub, L. Boswinkel, T. Euiss, The geopolitical implications of the COVID-19 pandemic, 2020. doi:10.2861/526114, https://www.europarl.europa.eu/RegData/etudes/STUD/2020/603511/EXPO_STU(2020)603511_EN.pdf [access date: 2021-02-08].

${ }^{4}$ Edge Foundation, The Impact of COVID-19 on Education: evidence on the early impacts of lockdown, London 2020; International Commission on the Futures of Education, Education in a post-covid world: Nine ideas for public action. Paris: UNESCO, 2020.

5 M. H. Nguyen, J. Gruber, J. Fuchs, W. Marler, A. Hunsaker, E. Hargittai, Changes in Digital Communication During the COVID-19 Global Pandemic: Implications for Digital Inequality and Future Research. "Social Media + Society", 2020 6(33), pp. 1-6, https://doi.org/10.1177/2056305120948255.

6 OECD, The impact of the coronavirus (COVID-19) crisis on development finance, 2020, https://read.oecd-ilibrary.org/view/?ref=134_134569-xn1goli113\&title=Theimpact-of-the-coronavirus-(COVID-19)-crisis-on-development-finance [access date: 2021-02-08].

7 D. Kubacka-Jasiecka, Interwencja kryzysowa. Pomoc $w$ kryzysach psychologicznych [Crisis intervention. Assistance in psychological crises]. Warszawa 2010; 
are doing) has affected us suddenly and has forced us, among other things, to reorganise the order of our daily lives. The previous complex cycle of everyday activities, combining various devices, material objects and people ${ }^{8}$, has become even denser, as our residential space has become "the whole world of ours". It used to be the place of carrying out daily chores, but now it is also the site of doing various tasks remotely. One of many consequences of remote functioning is the multiplicity of devices. Computers, cameras, microphones, adapters, routers - they have all become necessary to maintain the daily cycles of remote activities. They have taken the user out of a specific time-space and placed them in the virtual reality with its 'timeless time' (Castells, 2007) 9 and 'space of flows'10.

Education is one of the areas affected by change. The rules previously organising the didactic process, concerning the space, time, specificity of educational interactions and studying, regarded by David Tyack and William Tobin ${ }^{11}$ as the elements of grammar of schooling, have been transformed. By decision of the Minister of Science, since March 2020, the functioning of universities has been limited as regards the process of stationary education ${ }^{12}$. The distance mode of education was

J. Qiu, B. Shen, M. Zhao et al., A nationwide survey of psychological distress among Chinese people in the COVID-19 epidemic: implications and policy recommendations. General Psychiatry, 2020, 33. DOI: 10.1136/gpsych-2020-100213.

${ }^{8}$ M. Krajewski, Dzisiaj jak wczoraj, jutro jak dziś. Codzienność, przedmioty, reżimy podtrzymujące [Today as yesterday, tomorrow as today. Everyday life, objects, sustaining regimes], In: Barwy codzienności. Analiza socjologiczna [The colours of everyday life. A sociological analysis], eds. M. Bogunia-Borowska, Warszawa 2009, p. 178.

9 M. Castells, Społeczeństwo sieci [The Rise of the Network Society], Warszawa 2007.

${ }_{10}$ M. Castells, Władza komunikacji [Communication Power], Warszawa 2013.

${ }^{11}$ D. Tyack, W. Tobin, The "grammar" of schooling: Why has it been so hard to change? "American Educational Research Journal" 1994 no (31)3, p. 454. DOI: https://doi.org/10.3102\%2F00028312031003453.

12 Rozporządzenie Ministra Nauki i Szkolnictwa Wyższego z dnia 11 marca 2020 r. $w$ sprawie czasowego ograniczenia funkcjonowania niektórych podmiotów systemu szkolnictwa wyższego i nauki $w$ związku z zapobieganiem, przeciwdziataniem i zwalczaniem COVID-19 [Regulation of the Minister of Science and 
used until the end of the 2019/20 academic year and could be continued from October 2020, at the discretion of each rector. Universities were not prepared to this in terms of computer equipment, teacher educators' qualifications, possibility of having all the subjects included in the curriculum (e.g., student placements or subjects taught in the field) and verification of learning outcomes. The initial actions had the form of crisis intervention, responding to the current situation so as to protect what was the most important. The whole load of coping with the situation was on the shoulders of teachers and the management staff of particular university departments ${ }^{13}$. In the beginning, the difficulty of carrying out the process of education lay in the vast scope of organizational issues and the impossibility to determine the time perspective for it. Many believed that the lockdown was temporary and they would return to "regular" classes one day. After a year of education in this mode, the initial confusion ${ }^{14}$ has given way to the sense of familiarity, but also to exhaustion and growing yearning for the "normal life".

This paper reports the findings of the study of selected elements of school grammar (temporal and spatial organization, learning interactions $)^{15}$. The study presented in this article focuses on the experiences of students' who had learned in the coronavirus pandemic.

Higher Education (2020). of 11 March 2020 on the temporary restriction of the operation of certain entities of the higher education and science system in connection with the prevention, counteraction and combating of COVID-19], Journal of Laws Dz.U. 2020, item 405.

${ }^{13}$ P. Topol, Metody i narzędzia kształcenia zdalnego $w$ polskich uczelniach w czasie pandemii COVID-19 - Część 1, Dyskusja 2020 [Distant Learning Methods and Tools in Polish Higher Education During the COVID-19 Pandemic - Part 1, 2020 Debate]. „Studia Edukacyjne”, 2020 no 58, pp. 69-83. DOI: 10.14746/ se.2020.58.4.

${ }^{14}$ M. Czerepaniak-Walczak, Jak zmienia się „gramatyka edukacji”? O przejawach $i$ konsekwencjach (wymuszonej) iedukacji [How is the "Grammar Of Schooling" Changing? About the Phenomena and Consequences of Forced Ieducation]. "Forum Oświatowe", 2020 no 32(1), p. 17. DOI: https://doi.org/10.34862/ fo.2020.1.1.

${ }^{15}$ D. Tyack, W. Tobin, The "grammar" of schooling: Why has it been so hard to change? "American Educational Research Journal", 1994 no 31(3), pp. 453-479. 


\section{Grammar of schooling - what is it?}

David Tyack and William Tobin use the term "grammar of schooling" to refer to the regular structure and permanent rules of organizing schoolwork, including the standard organizational practices concerning the division of time and space, splintering of knowledge into subjects, evaluation and classification, and division of learners based on their age ${ }^{16}$. The organizational patterns seem normal and non-questionable. They are not "ahistorical creations etched in stone. They are the historical product of particular groups with particular interests and values at particular times"17. Thus, they are of political origin and their form is chosen by state officials, political elites, university professors, teachers, and other bodies having an impact on school ${ }^{18}$. Reforms of education are based on the belief that if people have created the institutional framework, they can and should change it if it no longer serves humanitarian goals". The "grammar of schooling" has its rules. You do not need to understand their specificity to observe them. Tyack and Tobin highlight the analogy to the grammar of a language: you do not really need to understand the specificity of grammatical rules observed while speaking in order to be able to speak fluently and efficiently.

The analysis of grammar of schooling helps us understand the functioning of school everyday reality, but also recognize the mechanisms of preserving institutional continuity and changes that take place ${ }^{20}$. The experience of the coronavirus pandemic means that we are living in a time of many dramatic changes, including a change in what is perceived as a "real school".

16 Ibid, p. 454.

17 Ibid, p. 476.

18 Ibid, p. 476.

19 Ibid, p. 471.

20 M. Czerepaniak-Walczak, Kultura szkoty, jej trwanie zmiana. O sile oddziaływania "gramatyki szkoty" [School Culture, Continuity and Change. On the Power of a "School Grammar"], "Czas Kultury", 2020 no 1(204), pp. 13-19. 


\section{Study design}

\section{Participants and context}

This article reports on data collected from 64 1st year pedagogy students. The participants of this study were predominantly female. This group of students was selected because they experienced the lockdown two times: 1) in March 2020, two months before the scheduled secondary school final (maturity) exam; 2) in November 2020, at the beginning of their university education. The aim was not to establish differences between these periods, they were treated as a period of 'different' - COVID teaching. The research was carried out in December and 2020 and January 2021. The university where the research was carried out operated in the stationary mode for one month and changed to the remote mode in November 2020.

\section{Data collection, analysis and ethical considerations}

The aim of the research was to analyse the experiences of 1st year pedagogy students connected with change of the grammer of schooling during the coronavirus pandemic. The research question was: what picture of organizational practices regarding time, space, and relationships emerges from the experiences of first-year pedagogy students studying during the coronavirus pandemic? The research was carried out as part of classes in the Basics of Pedagogy. After a class concerning the structure of pedagogical terms, the students were asked to discuss the issue of changes in the grammar of schooling. The aim of the seminar was to stimulate the students to reflect on the key terms in pedagogy from the perspective of their own experiences related to education in the time of the pandemic. The diversity of students' responses and their engagement in sharing their experiences led to the idea to do this research. The data were collected through questionnaire with openended questions about the changes students experienced due to the coronavirus pandemic in areas such as the organisation of space, the 
organisation of time, learning interactions, forms of work, as well as the expected consequences of the changes they are currently witnessing and the anticipated 'return to normality'. All participants were informed about the purpose of the study. Students gave written consent for their statements to be quoted in the research text. Nineteen students did not give permission for their written accounts to be quoted. They statements weren't used for analysis.

Responses to open-ended questions were coded according to Graham Gibbs' principles. First, responses were read as a body of material to identify initial categories and themes. Next, the responses of all students given within a question were gathered together and analyzed vertically (for categories and themes emerging from other questions) and horizontally (for all themes and categories emerging from the material). This analysis was intended to identify analytical categories that form a picture of the changes in the organization of time, space, and interaction experienced by students studying during the coronavirus pendemic.

\section{Results}

The presentation of the results is organised around tree themes: (1) spatial organization; (2) temporal organization; and (3) educational interactions.

\section{Spatial organization}

\section{The reorganisations of the space}

The spatial conditions that used to be provided by the university now must be ensured individually. The complex, multi-aspect space of school ${ }^{21}$ in which they functioned has been reduced to the space of their room, or even bed. The students describe it as follows: "My room, like

21 A. Nalaskowski, Przestrzenie i miejsca szkoty [School spaces and places], Kraków 2002. 
the rooms of other students', has become the "university"' [S10] ${ }^{22}$; "My bed very often serves as my workstation" [S1]. Students create their own "workstations" [S4]. Students decides individually what they need to "focus on studying" [S7] and to make the place likeable [S36]. The necessities are a laptop, a computer, a cell phone, a camera, and a microphone - objects not so long ago treated as atypical, innovative or even prohibited at school ${ }^{23}$. To meet this requirement, many students have had to reorganize the space in their room or on their desk. They made these changes with consideration of: 1) the need to be able to log in to classes (purchasing equipment, Internet access); 2) the awareness that others would see their room (renovation, redecoration); 3) the need to arrange the space so as to facilitate concentration and mental work [S10, S29] and to ensure "freedom and security" [S19]; 4) their own comfort. One student describes it this way: "My studying space is basically my bed. After I get up, I place my notebooks, notes and laptop on the bed, make myself some tea and breakfast, and I cover myself with a blanket. This is the most comfortable for me, I know I have everything handy and I can focus on studying" [S7]. Preparing a comfortable place and sitting still (on a bed, a soft carpet, at the desk or next to a heater) is the common experience of students nowadays. On the one hand, the space of their daily functioning has been greatly reduced, which "is sometimes overwhelming" [S39], and on the other hand, it is the result of their autonomous decisions and creation: the space may be cramped, but it is theirs.

When asked from what unusual places students had logged in for classes, the students mentioned: a mechanic's garage [S10], a shop [S8, S20], a dentist's surgery [S34], public transport or a train [S4], a car [S5, S20] and the toilet [S17]. Furthermore, they join the classes while

22 Students' utterances are in quotation marks. Students' codes are provided in square brackets.

23 M. Czerepaniak-Walczak, Jak zmienia się „gramatyka edukacji”? O przejawach i konsekwencjach (wymuszonej) iedukacji [How is the "Grammar Of Schooling" Changing? About the Phenomena and Consequences of Forced Ieducation]. "Forum Oświatowe", 2020 no 32(1), pp. 13-23. DOI: https://doi.org/10.34862/ fo.2020.1.1. 
doing other things, e.g., walking the dog [S7], conducting a lesson at school [S19], or putting on make-up in the bathroom [S29]. University space has become flexible. Students have gained greater mobility and freedom to choose the best place for them or to do several things at the same time, which is well highlighted by one student: "I can take my "school" wherever I want" [S12]. However, there is some doubt concerning the student's concentration during such "classes" combined with shopping...

\section{Shifting privacy boundaries}

Bringing education home has led to changes in the functioning of all the family members. The crucial thing is to respect the fact that the student is taking part in classes and cannot be disturbed. One student reports: "I also had to make my parents realize that during the classes I'm unavailable, like I was normally at school" [S4]. At home there are often several people (and often also animals), so there are a lot of sounds and smells, which makes it much more difficult to focus on the classes [S24, S17, S37]. Trying to achieve some comfort for themselves and privacy for other family members, students isolate themselves in their rooms. Not only them, but also their family members, in a way have lost the "right to hide in the intimacy of their own home ... and to behave as they wish" 24 . Families have had to work out their own rules of privacy protection, e.g., staying in a particular space, using a background, muting microphones, informing others that their classes begin, etc. The sense of privacy loss is aggravated by the awareness that the camera and microphone may be on at any time and the image and sound can be recorded [S24]. This is especially difficult if more than one person at home have online classes simultaneously.

24 A. Młynarska-Sobaczewska, Trzy wymiary prywatności. Sfera prywatna i publiczna we wspótczesnym prawie i teorii społecznej [Three dimensions of privacy. Public and private spheres in the contemporary legal system and social theory]. "Przegląd Prawa Konstytucyjnego", 2013 no 1(13), p. 46. 
Distance learning has moved the boundaries of privacy understood as "the right to be the author of your own biography"25. Beate Roessler identifies the following privacy dimensions: the right to decide about your body (body privacy, physical privacy), informational privacy, i.e., the autonomy in determining the range of information about yourself that you make available, and the third one, which can be called local privacy, which involves the autonomy in choosing your behaviors and relationships within the family, home, and community"26. Students have received more privacy in the sphere of deciding about their body, which is evidenced by less care about their appearance and clothes than in the times of stationary education. The possibility to turn off the camera has reduced the importance of "personal faćade" 27 and made students' bodies their personal thing again.

Logging in to classes, the use of e-mail and various applications, sharing materials with a group, sending photos, documents etc. is an unending process of making personal information available. According to students, the loss of informational privacy is mainly caused by the need to turn on the camera. The participants write: "We all in a way had to force ourselves to turn on the cameras, to show ourselves, to show a part of our private space" [S13]. It is interesting that whereas students do not like to show their face during the classes, they share huge amounts of information about themselves on various forums and social networks. This shows how fluid and subjectively defined are the boundaries of informational privacy.

Since their room is no longer a private space but the scenery of didactic activities, students give a lot of attention to its cleanliness. Tidying has become an element of preparing to classes and creating one's image. A student explains: "Usually during the classes I sit at my desk.

25 B. Roessler in A. Młynarska-Sobaczewska, Trzy wymiary prywatności. Sfera prywatna i publiczna we współczesnym prawie i teorii społecznej [Three dimensions of privacy. Public and private spheres in the contemporary legal system and social theory], "Przegląd Prawa Konstytucyjnego", 2013 no 1(13), p. 35.

26 Ibid.

27 E. Goffman, Człowiek $w$ teatrze życia codziennego [The Presentation of Self in Everyday Life], Warszawa 2008. 
Whenever I have to turn on my camera, the part of the room that the others can see is perfectly clean, but the rest of the room is a mess" [S35]. The room was divided into two zones: visible and invisible in the camera (like the front stage and the backstage in Goffman's theory). The former is formal, orderly, perfect and neat, ready to be shown to others, adequate to the image one is trying to create. If it is not so tidy, it is covered with any "background". The latter is private, hidden from the viewers, less attractive, and not deserving so much care. The same refers to students' body and outfits, which a female student describes this way: "Most people use a ready background to hide a messy room. As for me, only the upper part of my body is often dressed up, because nobody can see the lower part anyway" [S37].

Cleaning has become "an activity necessary for proper functioning" [S9] or, as ${ }^{28}$ calls it, a regime sustaining the daily reality. Dusting, washing, sorting... "Household chores have actually become a nice change from studying... who would think so?" [S9]. Tired with the daily routine, students find cleaning pleasant and treat cleanliness as the source of freedom ${ }^{29}$. A tidy room and desk, apart from the esthetic aspect, play an important role in the process of studying: they enhance motivation and facilitate concentration. One student explains this: "I find it really hard to stay motivated during online classes, a lot of things make me lose focus, for example my phone or the very fact that I'm lying in bed, but when I began to study, a tidy room was a motivation for me. When my room is not messy, I have greater motivation to learn and participate in classes" [S32].

28 M. Krajewski, „Dzisiaj jak wczoraj, jutro jak dziś. Codzienność, przedmioty, reżimy podtrzymujące" [Today as yesterday, tomorrow as today. Everyday life, objects, sustaining regimes], in: Barwy codzienności. Analiza socjologiczna [The colours of everyday life. A sociological analysis], eds. M. Bogunia-Borowska, Warszawa 2009, p. 181.

29 M. Zawodna-Stephan, Od umęczonego ciała do zmęczonej duszy. Krótki szkic ze społecznej historii zmęczenia [From tired body to tired soul. A brief sketch from the social history of fatigue], "Kultura Współczesna", 2016 no 3, pp. 23-35. 


\section{Temporal organization}

\section{Time frozen in a stop frame}

Although classes in which students take part at home give their day some structure, they are not necessarily treated as the crucial, most important event. For many students, they are the "background" for other activities. During the classes, they discreetly do some things: 1) to sustain the daily life of all the family members (washing, cleaning, cooking), 2) to help younger siblings (assisting them in logging in to their online classes), 3) for self-creation (doing some arts), 4) for pleasure (listening to music, playing computer games, playing the piano), 5) for health (walking, working out). In most cases, this multitasking is not the result of the excess of tasks planned for the day or of being busy ${ }^{30}$ but rather an expression of "time deepening" 31 . Students let the time of their responsibilities and their free time overlap, when they go for a walk, have a meal, talk to someone or pet their cat. They mix activities of different kinds: obligatory with voluntary, private with public, those done for others with those done only for themselves.

Although classes take place according to the institutional schedule, students organize their time themselves, particularly deciding how to spend it. Unlike before, they are not "doomed" to follow the teacher's proposals. Now, individually organizing their time and space, they can plan the scope and pace of activities they do during the day, diversify, and protect themselves from boredom. A day has lost its linear order. Distance learning disturbs the clarity of division into working time and leisure time ${ }^{32}$. Currently, everything is going on simultaneously, e.g.,

30 J. Gleick, Szybciej. Przyspieszenie niemal wszystkiego. [Faster: The Acceleration of Just About Everything], Poznań 2003; M. Castells, Władza komunikacji [Communication Power], Warszawa 2013.

31 J. Robinson, G. Godbey, G., Time for Life: The Surprising Ways Americans Use Their Time. With a Foreword R.D. Putnam. The Pennsylvania State University Press, 1997, p. 39.

32 E. Tarkowska, Czas społeczny a czas wolny: koncepcje i współczesne przemiany [Social time and leisure time: concepts and contemporary transforma- 
studying and lying in bed, eating, or playing, so everything has become ordinary, less distinct and less attractive. Students' days have become a repeated, quite monotonous cycle of activities, including too few "crazy", extraordinary things, so much appreciated by young people and associated with the time of university education. Days fuse into repeatable, ordinary routine. Time has stopped, like a freeze-frame. One of the students describes it in an interesting way: "Online classes have lost their value, they are nothing special any more. There have been situations when I was answering the teacher's question while driving, walking the dog, doing shopping, or I was even "listening" in my sleep. E-lessons and e-breaks are just about the same thing. During the break, I can eat like I did during the lesson, and I'm still lying on the same couch" [S6].

Although classes attended at home have lost their prestige, they still have the relational importance: they are the reason and content of establishing and maintaining interactions between students (they facilitate conversations by providing shared experiences or membership in the same project group).

\section{Advantages and disadvantages of home time organization}

In the temporal dimension, students point both to advantages and disadvantages of this way of schooling. The disadvantage is that preparing to classes with the use of materials the teachers send or the students find by themselves is very time-consuming [S11]. Sitting in front of the computer for many hours a day has a number of negative consequences for students' mental and physical health status: "frequent headaches, tired eyes, depressive mood, sitting at home all the time" [S27]. The advantages mentioned by the respondents are saving the time normally spent on commuting to the university or waiting for the next class ("openings"). An important benefit is the possibility to sleep longer and no need to be ready on time.

tions], in: Kobieta i kultura czasu wolnego [Woman and the culture of leisure], eds. A. Żarnowska, A. Szwarc, vol VII, Warszawa 2001, p. 23. 
Being constantly at home reduces the need to plan and control the use of time. On the one hand, this gives the students the feeling of freedom and comfort due to less pressure. On the other hand, it may make them stop expecting anything from themselves, and the university may become little more than a café where they meet friends. This is illustrated by one student's observation: "A huge advantage is that I can stay in a warm home, in bed, drinking coffee. We have the uni at home, we can say the teachers and the student group are present at our homes" [S10]. The analysis of research results shows that students are turning into viewers (like they were watching TV), passively sitting in front of the screen, or "simple audience" 33 watching the teacher's performance (like a game or concert).

\section{Educational interactions}

\section{The invisible class participants}

If a teacher or student took a photo during a class, it would look the same from the perspective of each participant: the screen full of rectangles with participants' initials or photos (not necessarily of themselves), names and surnames, with microphones and cameras turned off. Very often the teacher is the only person who turns the video and audio on, at least for a moment. During many classes, students do not do so even once. In the respondents' view, the present conditions of educational interactions have been distorted [S19] and are "not normal" [S13], mainly because they are dependent on technical equipment and its reliability. From students' perspective, a working microphone is much more important than a camera, since it is the lack of sound, voice overlapping or lagging that hampers communication. Words prove to be more valuable than images.

The analysis of students' responses revealed a kind of paradox related to turning on the camera. Most students feel comfortable when their cameras are off, but they would like to see the teacher and other

33 N. Abercrombie, B. Longhurst, Audiences. A Sociological Theory of Performance and Imagination, London-Thousand Oaks-New Delhi 1998, p. 69. 
students. Being able to see other people elevates their mood, has a positive impact on the atmosphere, and promotes feedback. On the other hand, they point to a number of emotional benefits of having their own cameras off: the sense of security, freedom, peace, lower levels of stress and embarrassment. A student admits: "Of course the work goes better when people have their cameras on, because then we can see each other and the classes are conducted in a completely different atmosphere, although I personally don't like turning the camera on, it's kind of embarrassing and stressful for me" [S34]. Being invisible makes them more courageous and willing to speak during the classes. They feel secure from abuse, such as recording, taking photos, or being "pinned" to the center of the screen. One student explains: "Regarding the interactions between students, I think we all feel more comfortable if we have the cameras off, because then we feel better, safer. It's not the same as talking face to face" [S7].

Class participants have become invisible (together with their outfits, gestures and personal characteristics), they have become emojis or mere images on the screen, they have put on masks. Discussing the issue of such personal faćade, Goffman wrote that the "front" informs others about the individual's social status and about the ritual they are actively participating $\mathrm{in}^{34}$. The masks the students hide behind are the carriers of freely transformed meanings (new faces). The student can change their identity any number of times, and the mask becomes a tool of multiple games with the identity ${ }^{35}$. It helps the students cope with functioning between two worlds: the real one and the virtual one. It gives them more freedom, allows them to speak more courageously, but also accept themselves and their own bodies (without the regime of beauty). It is also a form of counteracting loneliness and anonymity. It seems to be calling to each viewer for a single look or thought in case the two people never meet in person. The masks have become a kind of hiding place for students, which opens a number of interpretation possibilities.

34 E. Goffman, Człowiek $w$ teatrze życia codziennego [The Presentation of Self in Everyday Life], Warszawa 2008.

35 M. Jarmułowicz, Słowo wstępne [Foreword], [in:] Ogród sztuk. Maska [The Garden of Arts, Mask], ed. M. Jarmułowicz, Gdańsk 2017, p. 7. 
The students have divided their interactions based on: 1) the form of the classes: lectures, seminars; 2) the interacting people: teachers, students; 3) the interactions' character: formal, informal. Interactions during online lectures differ the least from those during lectures in the university hall. One student reports: "When we have lectures, it's really similar, because the lecturer is speaking and we are listening, it's the same as in the classroom" [S16]. But the interactions during seminars differ a lot. The students understand that the present way of conducting classes may be difficult for the teachers. They identify: 1) discomfort caused by students' cameras off [S20], 2) impossibility to see nonverbal signs, students' reactions (and thus, their understanding of the discussed material and the level of interest), 3) students' lack of openness and signalling that something is unclear, 4) students' lower concentration and engagement in discussions [S16], 5) reduced dynamics of classes - "Everything is slowed down by e-learning platforms and technical issues" [S17]. Working with the camera off means that the teacher conducts the classes at their own pace and presents the material in the order they choose. The teacher (often unconsciously) ignores the needs of students they cannot see (sometimes for many hours). One student describes it very emotionally: "During the classes I often have something to say but I don't speak up, because someone else turns on the microphone first or the teacher goes on with the material, not seeing that there is someone who also wants to say something. Actually, it would be hard to notice after long hours of looking at icons and pictures" [S6].

\section{The discrepancy between the reality and the expectation from studying}

Students experience some discrepancy between what is going on in the reality and what they expected from studying as regards student-student interactions. They may react to this in two ways: 1) engaging in various activities to maintain relationships in the student group; 2) narrowing the relationships to family members, and only other students contacting in connection with tasks done together. The first group (the vast majority) try to build and maintain mutual relations regardless 
of difficulties, using various mediated communication channels (chats, forums, social networks etc.) via which they "normally communicate" [S36]. Research shows that people who send e-mails, chat, surf the Internet and engage in other interactive practices consider them as completely real ${ }^{36}$. One student shares this view: "We write a lot to each other, exchange our reflections and support others. I have the impression that although we can't see each other, our relations are even closer and we help each other even more" [S4]. Students display interest in others, support and kindness. They want to belong to the community and maintain the "relationship temperature" high. This is proved by the following responses: "After classes we have very good relationships with the group, we are interested in each other. [...] What's hard for me is that I'm not always sure who says what, because I can only see chat icons. Communication using chats or e-mails is nice because you can get back to it and remember the information, but on the other hand, we can't always express 100\% what we want" [S12]. "We have contact with the rest of the group via communicators such as Messenger. [...] Although I can't see their faces every day, I know we are a strong group" [S10]. Students miss the deep relationships which require, not only common experiences, but also subtle reactions only possible in direct relationships ${ }^{37}$. One student explains: "In the classroom we can always whisper something to someone or discreetly exchange looks. Now we don't have this, so usually when we want to talk about something, we just write on the Messenger group" [S16]. The consequence of impossibility to talk about everyday experiences is the "impression of isolation" [S28]. Two people feel that interactions between students

36 A. Wittel, W stronę społecznego uspołecznienia. Netwroking jako praktyka społeczna [Toward socialization. Networking as a social practice], „Kultura Popularna", 2010 no 1(27), pp. 159.

37 See: J. Pyżalski, W. Poleszak, Relacje przede wszystkim - nawet jeśli obecnie jedynie zapośredniczone [Relationships above all - even if currently only mediated], in: Edukacja w czasach pandemii wirusa COVID-19. Z dystansem o tym, co robimy obecnie jako nauczyciele [Education in the time of the COVID-19 virus pandemic. With a distance about what we are doing as teachers now, ed. J. Pyżalski, Warszawa 2020. 
have become more formal and mainly refer to issues connected with the classes [S1].

To sum up, students mix different ways of communication: using words, images and emojis. Formal interactions mostly have the form imposed by the teacher. Students cognitively engage in the classes, but they reserve the emotional engagement for informal student-student relations.

\section{Conclusion}

The analysis of students' experiences has shown what changes are occurring in the grammar of schooling. If we looked at the practice of distance education from a broader perspective we recognize that currently university has become a virtual network of students' rooms located all over the region, country, or even world (it does not matter any longer), where they 1) begin the time-synchronised learning process when they log in to classes; 2) do the tasks chosen by the teacher or by themselves at any time they prefer. The key change observed in students' education is that the teachers and learners do not have to be in the same time-space any more. Teacher educators have lost the control of the time and space in which the students learn. The least change occurred in the relationships between teachers and students: they are still formal and focused on the teaching content. The change in student-student interactions involves the loss of direct contacts and intensification of the frequency and number of mediated communication channels ${ }^{38}$.

Students are experiencing a change in the familiar structures and principles of schoolwork organisation. They feel that remote education is not "real, normal school", but they also are getting used to this situation and would find it more and more difficult to return to the university building. Their experience can be defined as being absorbed by everyday life, sucked into repeated, daily cycles of activity. This is ac-

38 M.H. Nguyen, J. Gruber, J. Fuchs, W. Marler, A. Hunsaker, E. Hargittai, Changes in Digital Communication During the COVID-19 Global Pandemic: Implications for Digital Inequality and Future Research, "Social Media + Society", 2020 no 6(33), pp. 1-6. DOI: https://doi.org/10.1177/2056305120948255. 
companied by the students' lower mood, feeling a decrease in the value of their studies, and the sense of living in a unique period of time. It is worth monitoring the consequences of this situation for students' wellbeing and the quality of qualifications they acquire.

Based on study findings, it is hard to guess how they will evolve, because their course depends on many social and political factors ${ }^{39}$. It is still too early to evaluate the changes, because we are still living in the COVID world and experiencing this situation ${ }^{40}$. There are voices that nothing will change because the systems of education are still subject to market $\operatorname{logic^{41}}$ or that there will be a series of transformations in the concept of higher education institutions, their participants, and practices $^{42}$.

\section{References:}

Abercrombie, Nick, Longhurst, Brian. Audiences. A Sociological Theory of Performance and Imagination. London-Thousand Oaks-New Delhi: Sage, 1998.

Ali, Hussain, Yilmaz, Gözde, Fareed, Zeeshan, Shahzad, Farrukh, Ahmad, Munir, "Impact of novel coronavirus (COVID-19) on daily routines and air environment: evidence from Turkey". Air Quality, Atmosphere \& Health 14 (2021): 381-387. DOI: https://doi.org/10.1007/s11869-020-00943-2.

Borkowska, Iwona. "Czas wolny w problematyce zdrowia i choroby" [Leisure time in health and illness]. In: Czas wolny. Refleksje, dylematy, perspekty-

39 R. Hofstetter, B. Schneuwly, Changes in Mass Schooling: school form and grammar of schooling as reagents. European Educational Research Journal, 2013 no 12(2), pp. 166-175. DOI: https://doi.org/10.2304/eerj.2013.12.2.166.

40 S. J. Courtney, B. Mann, Thinking with 'lexical' features to reconceptualize the 'grammar' of schooling: Shifting the focus from school to society, "Journal of Educational Change", (2020). DOI: https://doi.org/10.1007/s10833-020-09400-4.

${ }^{41}$ Ibid.

${ }^{42}$ R. Gurukkal, Will COVID-19 Turn Higher Education into Another Mode? "Higher Education for the Future", 2020 no 7(2), pp. 89-96, DOI: 10.1177/2347631120931606. 
wy [Leisure time. Reflections, dilemmas, perspectives], ed. Dorota Markowska, 89-102. Warszawa: Difin SA, 2011.

Brooks, Samantha K., Webster, Rebecca K. Smith, Louise E. Woodland, Lisa, Wessely Simon, Greenberg Neil, et al. "The psychological impact of quarantine and how to reduce it: rapid review of the evidence". Lancet 395 (2020): 912-920. DOI: https://doi.org/10.1016/.

Buchner, Anna, Majchrzak, Marta, Wierzbicka, Maria. Edukacja zdalna w czasie pandemii. Raport z badań [Remote education during a pandemic. Research report]. Centrum Cyfrowe 2020. https://centrumcyfrowe.pl/edukacja-zdalna/\#Raport.

Castells, Manuel. Społeczeństwo sieci [The Rise of the Network Society]. Warszawa: Wydawnictwo Naukowe PWN, 2007.

Castells, Manuel. Władza komunikacji [Communication Power]. Warszawa: Wydawnictwo Naukowe PWN, 2013.

Courtney, Steven J., Mann, Bryan. “Thinking with 'lexical' features to reconceptualize the 'grammar' of schooling: Shifting the focus from school to society". Journal of Educational Change 2020. DOI: https://doi.org/10.1007/ s10833-020-09400-4.

Czerepaniak-Walczak, Maria. „Jak zmienia się „gramatyka edukacji”? O przejawach i konsekwencjach (wymuszonej) iedukacji" [How is the "Grammar Of Schooling" Changing? About the Phenomena and Consequences of Forced Ieducation]. Forum Oświatowe 32/1 (2020): 13-23. DOI: https://doi. org/10.34862/fo.2020.1.1.

Czerepaniak-Walczak, Maria. „Kultura szkoły, jej trwanie zmiana. O sile oddziaływania »gramatyki szkoły«" [School Culture, Continuity and Change. On the Power of a "School Grammar"]. Czas Kultury 1/204 (2000): 13-19.

Drozdowski, Rafał, Frąckowiak, Maciej, Krajewski, Marek, Kubacka, Małgorzata, Modrzyk, Ariel, Rogowski, Łukasz, Rura, Przemysław, Stamm, Agnieszka. Życie codzienne w czasach pandemii. Raport z pierwszego etapu badań [Everyday life in times of pandemic. Report on the first phase of research]. Poznań: Uniwersytet im. A. Mickiewicza w Poznaniu, 2020.

Edge Foundation. The Impact of COVID-19 on Education: evidence on the early impacts of lockdown. London: Edge Foundation, 2020.

Gardini, Gian. Luca (ed.). The World before and after COVID-19. Intellectual reflections on politics, diplomacy and international relations. Salamanca Stockholm: European Institute of International Studies, 2020. 
Gaub, Florence, Boswinkel, Lotje, Euiss, Trainee. The geopolitical implications of the COVID-19 pandemic, 2020. DOI: 10.2861/526114 Accessed: https:// www.europarl.europa.eu/RegData/etudes/STUD/2020/603511/EXPO_ STU(2020)603511_EN.pdf.

Gibbs, Graham. Analiza danych jakościowych [Analyzing Qualitative Data]. Warszawa: Wydawnictwo Naukowe PWN, 2011.

Gleick, James. Szybciej. Przyspieszenie niemal wszystkiego. [Faster: The Acceleration of Just About Everything], Poznań: Zysk i S-ka, 2003.

Goffman, Ervin. Człowiek $w$ teatrze życia codziennego [The Presentation of Self in Everyday Life]. Warszawa: Wydawnictwo Naukowe PWN, 2008.

Gurukkal, Rajan. „Will COVID-19 Turn Higher Education into Another Mode?" Higher Education for the Future 7/2 (2020): 89-96, DOI: $10.1177 / 2347631120931606$.

Hofstetter, Rita, Schneuwly, Bernard. "Changes in Mass Schooling: school form and grammar of schooling as reagents". European Educational Research Journal 12(2) 2013: 166-175. DOI: 10.2304/eerj.2013.12.2.166.

International Commission on the Futures of Education, Education in a post-COVID world: Nine ideas for public action. Paris: UNESCO, 2020.

Jarmułowicz, Małgorzata. Słowo wstępne [Foreword]. In: Ogród sztuk. Maska [The Garden of Arts. Mask]. ed. Małgorzata Jarmułowicz, 7-13. Gdańsk: Wydawnictwo Uniwersytetu Gdańskiego, 2017.

Kituyi, Mukhisa, Durant, Isabelle, Owoko, Daniel, Coke-Hamilton, Pamela. The Impact of the COVID-19 Pandemic on Trade and Development: Transitioning to a New Normal. New York: United Nations Publications, 2020.

Krajewski, Marek. Dzisiaj jak wczoraj, jutro jak dziś. Codzienność, przedmioty, reżimy podtrzymujacee. [Today as yesterday, tomorrow as today. Everyday life, objects, sustaining regimes. In: Barwy codzienności. Analiza socjologiczna [The colours of everyday life. A sociological analysis]. ed. M. Bogunia-Borowska, p. 178-200. Warszawa: Wydawnictwo Naukowe SCHOLAR, 2009.

Kubacka-Jasiecka, Dorota. Interwencja kryzysowa. Pomoc w kryzysach psychologicznych [Crisis intervention. Assistance in psychological crises]. Warszawa: Wydawnictwa Akademickie i Profesjonalne, 2010.

Młynarska-Sobaczewska, Anna. „Trzy wymiary prywatności. Sfera prywatna i publiczna we współczesnym prawie i teorii społecznej” [Three dimensions of privacy. Public and private spheres in the contemporary legal system and social theory]. Przegląd Prawa Konstytucyjnego 1/13 (2013): 33-52. 
Nalaskowski, Aleksander. Przestrzenie i miejsca szkoły [School spaces and places]. Kraków: Oficyna Wydawnicza „Impuls”, 2002.

Nguyen, Minh Hao, Gruber, Jonathan, Fuchs, Jaelle, Marler, Will, Hunsaker, Amanda, Hargittai, Eszter. "Changes in Digital Communication During the COVID-19 Global Pandemic: Implications for Digital Inequality and Future Research". Social Media + Society 6/3 (2020): 1-6. DOI: https://doi. org/10.1177/2056305120948255.

OECD. The impact of the coronavirus (COVID-19) crisis on development finance, 2020. https://read.oecd-ilibrary.org/view/?ref=134_134569-xn1goli113\&title=The-impact-of-the-coronavirus-(COVID-19)-crisis-on-development-finance.

Pyżalski, Jacek, Poleszak Wiesław. Relacje przede wszystkim - nawet jeśli obecnie jedynie zapośredniczone [Relationships above all - even if currently only mediated]. In: Edukacja w czasach pandemii wirusa COVID-19. Z dystansem o tym, co robimy obecnie jako nauczyciele [Education in the time of the COVID-19 virus pandemic. With a distance about what we are doing as teachers now]. ed. Jacek Pyżalski, 28-36. Warszawa: EduAkcja, 2020.

Qiu, Jianyin, Shen, Bin, Zhao, Min, Wan, Zheng, Xie, Bin, Xu, Yifeng. "A nationwide survey of psychological distress among Chinese people in the COVID-19 epidemic: implications and policy recommendations". General Psychiatry 33 (2020). DOI: 10.1136/gpsych-2020-100213.

Robinson, John, Godbey, Geoffrey. Time for Life: The Surprising Ways Americans Use Their Time. The Pennsylvania State University Press, 1997.

Rozporządzenie Ministra Nauki i Szkolnictwa Wyższego (2020) z dnia 11 marca 2020 r. $w$ sprawie czasowego ograniczenia funkcjonowania niektórych podmiotów systemu szkolnictwa wyższego i nauki w związku z zapobieganiem, przeciwdziałaniem $i$ zwalczaniem COVID-19 [Regulation of the Minister of Science and Higher Education (2020). of 11 March 2020 on the temporary restriction of the operation of certain entities of the higher education and science system in connection with the prevention, counteraction and combating of COVID-19], Journal of Laws Dz.U. 2020, item 405.

Tarkowska, Elżbieta. Czas społeczny a czas wolny: koncepcje $i$ współczesne przemiany [Social time and leisure time: concepts and contemporary transformations], In: Kobieta i kultura czasu wolnego [Woman and the culture of leisure], eds. Anna Żarnowska, Andrzej Szwarc, 17-36. Warszawa: Wyd. DiG, 2001.

Topol, Paweł. Metody i narzędzia kształcenia zdalnego $w$ polskich uczelniach w czasie pandemii COVID-19 - Część 1, Dyskusja 2020 [Distant Learning Methods and Tools in Polish Higher Education During the COVID-19 Pan- 
demic - Part 1, 2020 Debate]. Studia Edukacyjne, 58 (2020): 69-83. DOI: 10.14746/se.2020.58.4.

Tyack, David, Tobin, William. "The "grammar" of schooling: Why has it been so hard to change?" American Educational Research Journal 31/3 (1994): 453-479. DOI: https://doi.org/10.3102\%2F00028312031003453.

WHO. COVID - 19 Strategy Update. World Health Organization, 2020 https:// www.who.int/docs/default-source/coronaviruse/COVID-strategy-update-14april2020.pdf?sfvrsn=29da3ba0_19.

Wittel, Andreas. „W stronę społecznego uspołecznienia. Netwroking jako praktyka społeczna" [Toward socialization. Networking as a social practice]. Kultura Popularna 1/27 (2010): 138-162.

Zawodna-Stephan, Marta. „Od umęczonego ciała do zmęczonej duszy. Krótki szkic ze społecznej historii zmęczenia" [From tired body to tired soul. A brief sketch from the social history of fatigue]. Kultura Wspótczesna 3 (2016): 23-35. 